\title{
Upaya Peningkatan Pengetahuan Tentang Pencegahan Covid- 19 dengan Perilaku Hidup Bersih, Sehat dan Gizi Seimbang di Panti Asuhan
}

\author{
Sumarni Marwang ${ }^{1}$, Jumrah Sudirman ${ }^{2}$ \\ 1,2Program Studi Kebidanan, Fakultas Keperawatan dan Kebidanan, \\ Universitas Megarezky, Jl. Antang Raya No. 43, Kota Makassar, Indonesia \\ Email: sumarni.megarezky@gmail.com ${ }^{1}$
}

\begin{abstract}
Abstrak
Berbagai upaya dilakukan untuk mencegah penularan corona virus. Pengobatan saat ini hanya untuk penanganan gejala yang muncul. Olehnya itu, peningkatan pengetahuan masyarakat dalam bentuk sosialisasi merupakan salah satu cara untuk upaya pencegahan. Perilaku hidup bersih dan sehat (PHBS) merupakan pola dalam kehidupan sehari-hari yang harus diterapkan untuk mencegah penularan. Saat ini dikenal 3 M (Memakai masker, Mencuci tangan dan Menjaga jarak) yang harusnya diterapkan oleh masyarakat agar mengurangi kejadian Covid19. Sosialisasi perlu dilakukan secara menyeluruh di seluruh lapisan masyarakat, termasuk di panti Asuhan. Target sosialisasi yang dilakukan oleh tim peneliti adalah Panti Asuhan AlFaqri di Antang. Dimana di kawasan panti menurut informasi dari kader posyandu setempat masih kurang pemahaman tentang wabah covid-19 yang saat ini terjadi. Olehnya itu, tim peneliti melakukan kegiatan sosialisasi pada Panti asuhan Al-Faqri untuk meningkatkan pengetahuan anak-anak panti tentang PHBS dan upaya pencegahan yang harus dilakukan untuk mencegah penularan covid-19.
\end{abstract}

Kata kunci : Perilaku hidup bersih dan sehat (PHBD), Pencegahan, Covid-19.

\section{Pendahuluan}

World Health Organization pada tanggal 31 Desember 2019 yang menyebutkan adanya kasus kluster pneumonia dengan etiologi yang tidak jelas di Kota Wuhan, Provinsi Hubei, China. Kasus ini terus berkembang hingga adanya laporan kematian dan terjadi importasi di luar China. Pada tanggal 30 Januari 2020, WHO menetapkan Covid-19 sebagai Public Health Emergency Of International Concem (PHEIC)/ Kedaruratan Kesehatan Masyarakat yang Meresahkan Dunia (KKMMD). Pada tanggal 12 Februari 2020, WHO resmi menetapkan penyakit novel coronavirus pada manusia ini dengan sebutan coronavirus disease (Covid-19). Pada tanggal 2 Maret 2020 Indonesia telah melaporkan 2 kasus konfirmasi Covid-19. Pada tanggal 11 Maret 2020, WHO sudah menetapkan Covid-19 sebagai pandemic [1].

Coronavirus adalah keluarga besar virus yang menyebabkan penyakit mulai dari gejala ringan sampai berat. Ada dua jenis coronavirus yang diketahui menyebabkan penyakit yang dapat menimbulkan gejala berat seperti Middle East Respiratory Syndrom (MERS) dan Severe Acute Respiratory Syndrome (SARS). Coronavirus disease 2019 (Covid-19) adalah penyakit jenis baru yang belum pernah diidentifikasi sebelumnya pada manusia. Virus penyebab Covid-19 ini dinamakan Sars-Cov-2. Virus Corona adalah zoonosis (ditularkan antara hewan dan manusia [2]. Penelitian menyebutkan bahwa SARS ditransmisikan dari kucing luwak (civet cats) ke manusia dan MERS dari unta ke manusia. Adapun hewan yang menjadi sumber penularan Covid-19 sampai saat ini masih belum diketahui [3].

Tanda dan gejala umum infeksi Covid-19 antara lain gejala gangguan pernapasan akut seperti demam, batuk dan sesak napas. Masa inkubasi rata-rata 5-6 hari dengan masa inkubasi terpanjang 14 hari. Pada kasus Covid-19 yang berat dapat menyebabkan pneumonia, sindrom pernapasan akut, gagal ginjal dan bahkan kematian. Tanda-tanda dan gejala klinis yang dilaporkan pada sebagian 
besar kasus adalah demam, dengan beberapa kasus mengalami kesulitan bernapas, dan hasil rontgen menunjukkan infiltrate pneumonia luas di kedua paru [4].

Berdasarkan data WHO penambahan jumlah kasus COVID-19 berlangsung cukup cepat dan sudah terjadi penyebaran antar negara. Sampai dengan 3 Maret 2020, secara global dilaporkan 90.870 kasus konfimasi di 72 negara dengan 3.112 kematian (CFR 3,4\%). Beberapa negara seperrti Republik Korea (4.812 kasus, 28 kematian), Jepang (268 kasus, 6 kematian), Singapura (108 kematian). Kasus corona virus di Indonesia terdeteksi sejak awal bulan februari 2020 virus corona di Indonesia per hari ini kamis 4 juni 2020 mencapai 28.818 orang yang tedeteksi. Pemerintah mengumumkan penambahan pasien sembuh sebanyak 486 dengan total seluruh yang mengalami kesembuhan perhari kamis 4 juni 2020 sebanyak 8.892 orang sedangkan untuk pasien yang meninggal dunia terdapat 23 orang sebanyak 1.721 orang. Angka ini menunjukkan bahwa peningkatan deteksi corona virus semenjak awal terdeteksi sampai hari ini melonjak tinggi [5].

Peningkatan dan penyebaran Corona virus - 19 di Makassar yang signifikan dan cepat serta diiringi dengan kejadian transmisi lokal di wilayah Kota Makassar Provinsi Sulawesi Selatan, bahwa berdasarkan hasil kajian epidemiologi dan pertimbangan kesiapan daerah dalam aspek sosial, ekonomi serta aspek lainnya, maka di kota makassar dilaksanakan Pembatasan Sosial Berskala Besar.Pemerintah Kota Makassar menggelar PSBB tahap pertama tanggal 24 April hingga 7 Mei 2020. Pada penerapan PSBB ini dampaknya cukup terlihat dari kurve peningkatan corona virus yang menjadi landau tetapi dipihak lain juga berdampak kepada sector perekonomian masyarakat sehingga dalam perencanaan penerapan PSBB tahap kedua banyak masyarakat yang tidak mengikuti anjuran pemerintah.

Oleh karena itu pemerintah kembali mempersiapkan New normal sebagai salah satu konsep tatanan, kebiasaan dan perilaku yang baru berbasis pada adaptasi untuk membudayakan perilaku hidup bersih dan sehat dan memperhatikan gizi seimbang inilah yang kemudian disebut sebagai new normal [6]. Cara yang dilakukan dengan rutin cuci tangan pakai sabun, pakai masker saat keluar rumah, jaga jarak aman dan menghindari kerumunan. kebiasaan baru ini harus menjadi kesadaran kolektif agar dapat berjalan dengan baik [3]. Siapa pun yang mengelola tempat umum, tempat kerja, sekolah dan tempat ibadah harus melakukan memperhatikan aspek ini. Untuk merealisasikan skenario new normal, saat ini pemerintah telah menggandeng seluruh pihak terkait termasuk tokoh masyarakat, para ahli dan para pakar untuk merumuskan protokol atau SOP untuk memastikan masyarakat dapat beraktivitas kembali, tetapi tetap aman dari COVID-19 [7]. Protokol ini bukan hanya di bidang ekonomi, tetapi juga pendidikan dan keagamaan, tentu bergantung pada aspek epidemologi dari masing-masing daerah, sehingga penambahan kasus positif bisa ditekan [8].

\subsection{Tujuan Kegiatan}

Tujuan dari kegiatan ini adalah untuk memberikan pengetahuan tentang wabah Covid-19 ini di kalangan anak-anak yang merupakan bagian dari maysrakat untuk dapat mencegah penularan wabah ini di masyarakat.

\subsection{Manfaat Kegiatan}

Adapun setelah pelaksanaan kegiatan ini didapatkan manfaat kegiatan yaitu peningkatan pengetahuan khususnya pada anak panti Al-Faqri di Antang, Makassar tentang perilaku hidup bersih dan sehat serta gizi seimbang sebagai upaya pencegahan covid-19.

\section{Realisasi Kegiatan}

\subsection{Bentuk Kegiatan \& Jadwal, Serta Tempat Kegiatan \\ a. Metode Pelaksanaan Kegiatan}

Kegiatan pengabdian ini menggunakan metode Ceramah dan Tanya Jawab dan Demonstrasi.

\section{b. Waktu Efektif Pelaksanaan Kegiatan}

Kegiatan Pengabdian Kepada Masyarakat ini dilakukan pada Bulan Juni 2020. 


\section{c. Tempat Kegiatan}

Kegiatan ini dilaksanakan di Panti asuhan Al-Faqri, di Antang Kota Makassar, Sulawesi Selatan.

\subsection{Hasil Pelaksanaan Pengabdian}

Setelah kegiatan dilaksanakan didapatkan hasil rata-rata anak panti asuhan Al-Faqri memiliki peningkatan prngrtahuan setelah dilaksanakan sosialisasi. Hal ini disimpulkan dari hasil pengelohan lembar ceklist sebelum dan setelah kegiatan melalui sesi tanya jawab oleh tim peneliti. Jumlah anak yang menjadi peserta kegiatan sebanyak 35 anak, dengan umur $<5$ tahun sebanyak 2 anak, 5-10 tahun sebanyak 13 anak, $10-<20$ tahun sebanyak 13 anak, dan $>20$ tahun 7 anak.

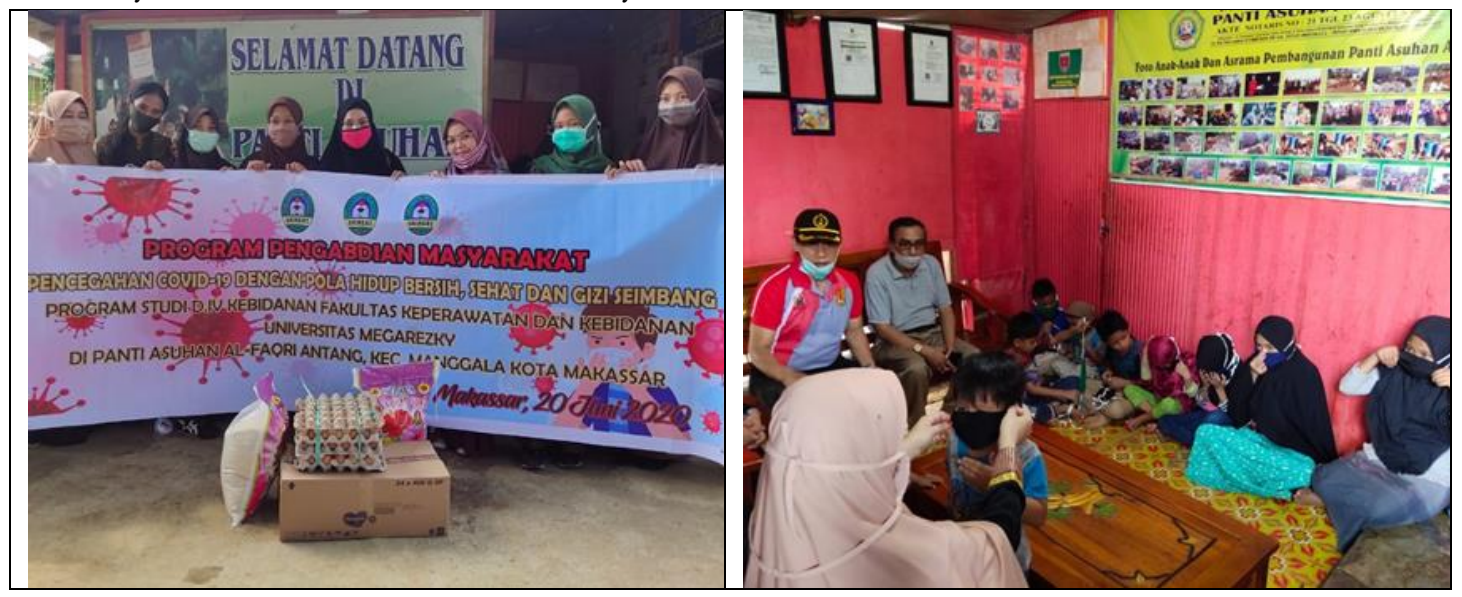

Gambar 1. Pelaksanaan Kegiatan

Dari 35 anak yang mengikuti kegiatan, terdapat 33 anak yang mengalami peningkatan pengetahuan dan terdapat 2 orang yang memiliki pengetahuan yang menetap. Peningkatan pengetahuan dipengaruhi oleh faktor umur anak dan pendidikan anak. 2 anak yang mengalami pengetahuan menetap dikarenakan umur yang masih kurang dari 5 tahun dan masih dalam umur bermain sehingga selama kegiatan pengabdian anak lebih banyak bermain.

Peningkatan pengetahuan anak sebanyak 33 orang diharapkan mampu menerapkan perilaku hidup bersih sehingga dapat mencegah penularan covid-19 yang terus mengalami peningkatan kasus. Penggunaan metode demonstrasi dalam kegiatan ini diharappkan menjadi metode yang dapat membuat anak belajar meniru. Hal ini sesuai dengan yang disampaikan oleh Bandura (1997) yang menyatakan bahwa belajar itu adalah proses meniru. Begitu juga dengan lingkungan. Adalah faktor yang sangat berpengaruh terhadap perilaku anak $[7,9,10]$.

\section{Tinjauan Hasil yang dicapai}

Kegiatan pengabdian masyarakat ini mampu meningkatkan pengetahuan responden dalam hal ini anak panti asuhan Al-Faqri. Hal ini sesuai dengan tujuan awal dilaksanakannya kegiatan pengabdian masyarakat ini dimana jumlah anak yang mengalami peningkatan pengertahuan yang baik terhadap perilaku hidup bersih dan sehat serta gizi seimbang sebagai upaya pencegahan covid-19 sebanyak 33 anak. Hal ini diharapkan dapat mencegah dan mengurangi penularan covid-10 di wilayah Makassar dan mencegah peningkatan kejadian covid-19. 


\section{Daftar Pustaka}

[1] Susilo, A., Rumende, C.M., Pitoyo, C.W., Santoso, W.D., Yulianti, M., Herikurniawan, H., Sinto, R., Singh, G., Nainggolan, L., Nelwan, E.J. and Chen, L.K., 2020. Coronavirus Disease 2019: Tinjauan Literatur Terkini. Jurnal Penyakit Dalam Indonesia, 7(1), pp.45-67.

[2] Nurislaminingsih, R., 2020. Layanan Pengetahuan tentang COVID-19 di Lembaga Informasi. Tik Ilmeu: Jurnal Ilmu Perpustakaan dan Informasi, 4(1), pp.19-38.

[3] Zulfa, F. and Kusuma, H., 2020. Upaya Program Balai Edukasi Corona Berbasis Media Komunikasi Dalam Pencegahan Penyebaran Covid-19. Jurnal Abdimas Kesehatan Perintis, 2(1), pp.17-24.

[4] Ilpaj, S.M. and Nurwati, N., 2020. Analisis Pengaruh Tingkat Kematian Akibat Covid-19 Terhadap Kesehatan Mental Masyarakat di Indonesia. Focus: Jurnal Pekerjaan Sosial, 3(1), pp.16-28.

[5] Putri, R.N., 2020. Indonesia Dalam Menghadapi Pandemi Covid-19. Jurnal Ilmiah Universitas Batanghari Jambi, 20(2), pp.705-709.

[6] Stang TASMJS., 2020. The Collaborative Model of Husbands and Health Officers Roles in Improving Mother's Behaviour Towards Providing Exclusive Breastfeeding: a Qualitative Study. Syst Rev Pharm. 11(11):350-4.

[7] Erlin, F., Putra, I.D. and Hendra, D., 2020. Peningkatan Pengetahuan Siswa Dalam Pencegahan Penularan COVID-19. JMM (Jurnal Masyarakat Mandiri), 4(4), pp.663-669.

[8] Yanti NPED, Nugraha IMADP, Wisnawa GA, Agustina NPD, Diantari NPA., 2020. Gambaran Pengetahuan Masyarakat tentang Covid-19 dan Perilaku Masyarakat di Masa Pandemi Covid-19. J Keperawatan Jiwa.Vol. 8 No.(3):485-90.

[9] Jaji, J., 2020, August. Pengaruh Pendidikan Kesehatan Dengan Media Leafletterhadap Pengetahuan Warga Dalam Pencegahan Penularan COVID 19. In Proceeding Seminar Nasional Keperawatan (Vol. 6, No. 1, pp. 135-140).

[10] Sulaeman, S. and Supriadi, S., 2020. Peningkatan Pengetahuan Masyarakat Desa Jelantik Dalam Menghadapi Pandemi Corona Virus Diseases-19 (Covid-19). Jurnal Pengabdian UNDIKMA, 1(1). 